\title{
Heat Stroke Caused by Electric Blanket: A Rare Surviving Case
}

\author{
Elektrikli Battaniyenin Neden Olduğu Isı \$̧oku
}

\author{
Kadir Gişi,, ${ }^{1}$ Nurhan KÖKSAL, ${ }^{2}$ Mehmet SAYARLIOĞLU,, ${ }^{3}$ Sedat KÖROĞLU, ${ }^{4}$ Harun ÇIRALIK ${ }^{5}$ \\ Departments of ${ }^{1}$ Gastroenterology, ${ }^{2}$ Thoracic Medicine, ${ }^{3}$ Rheumatology, \\ ${ }^{5}$ Pathology, Sutcu Imam University Kahramanmaras; \\ ${ }^{4}$ Department of Cardiology, Afsin State Hospital, Kahramanmaras, Turkey
}

\begin{abstract}
SUMMARY
Heat stroke caused by electric blanket is rare and challenging clinical condition. Limited numbers of cases were reported; most of them were postmortem. In this paper, a 60-year-old man survived after electric blanket mediated heat stroke, was described. Also, diagnostic methods, clinical presentation and management were discussed briefly in the light of current literature.
\end{abstract}

Key words: Electric injury; heat stroke; rhabdomyolysis.

\section{ÖZET}

Elektrikli battaniyenin neden olduğu ısı şoku sendromu nadir rastlanan bir klinik durumdur. Sınırlı sayıda olgu bildirilmiştir ve bunların çoğu ölüm sonrası bildirilerdir. Bu olgu sunumunda, elektrikli battaniyenin neden olduğu ısı şoku sonrası yaşamını sürdürebilen 60 yaşında bir erkek hasta bildirildi. Ayrıca, güncel literatür ışığında tanı metotları, klinik başvuru şekli ve hasta yönetimi tartışıldı.

Anahtar sözcükler: Elektrik yaralanması; ısı şoku; rabdomiyoliz.

\section{Introduction}

Electric blankets are widely used warming tools. Several accidents most commonly burning cases were reported due to inappropriate use. Besides, death cases were reported due to forgetting the electric blanket turn on and excessive heating of the individuals. Herein, we presented a rare surviving case of heat stroke because of electric blanket, which was initially misdiagnosed as pulmonary embolism.

\section{Case Report}

A 60-year-old man, admitted to emergency department with dyspnea, chest pain, fatigue, nausea, and diffuse body pain. His blood pressure was $80 / 40 \mathrm{mmHg}$, pulse was 110 / min, respiratory rate was $25 / \mathrm{min}$ and axillary temperature was $37.8^{\circ} \mathrm{C}\left(99.86^{\circ} \mathrm{F}\right)$. Lung examination revealed bibasilar rales. Skin was tense, swollen and hyperemic. All of the limbs were painful. There was only mild tachycardia on 12-lead electrocardiogram. Arterial blood gas analyses showed compensated metabolic acidosis and hypoxemia. D-dimer level was $2120 \mathrm{ng} / \mathrm{ml}$. He was hospitalized with the diagnosis of suspected acute pulmonary embolism. Immediate pulmonary computerized tomography angiography showed no signs of pulmonary embolism, also bilateral lower extremity venous color Doppler was normal. Cardiologic evaluation was entirely normal. Meanwhile additional laboratory tests were performed. They were shown in Table 1. Because of the diffuse muscle pain and increased muscle enzymes, he was consulted with neurology and rheumatology clinics. Electromyography was recommended and result was consistent with myopathy, thus muscle biopsy was performed. Parenteral steroid therapy was given to the patient because of suspected inflammatory myositis while awaiting the biopsy result. Muscle biopsy demonstrated that there was increased collagenized fibrous tissue in patches between muscle fibers and regenerative muscle fibers in some areas. No inflammatory infiltration was detected. Because of no definite clinical diagnosis despite detailed investigations, history of the patient was reexamined. He declared that he was slept on a very hot electric blanket before the onset of symptoms.

Submitted (Geliş tarihi): 22.05.2012 Accepted (Kabul tarihi): 29.07.2012 Published online (Online baskı): 07.02.2013

Correspondence (iletişim): Dr. Sedat Köroğlu. Afşin Devlet Hastanesi, Kardiyoloji Anabilim Dalı, 46100 Kahramanmaraş, Turkey.

e-mail (e-posta): m.sedatkoroglu@gmail.com

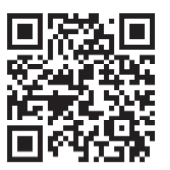


Table 1. Laboratory findings during hospitalization and follow-up

\begin{tabular}{|c|c|c|c|c|}
\hline Laboratory parameters & First admission & After 4 days & $\begin{array}{l}\text { Control values one } \\
\text { mounth after discharge }\end{array}$ & Normal ranges \\
\hline Glucose & 109 & 88 & 80 & $74-106$ \\
\hline WBC & 12.9 & 10.6 & 9.6 & $4.6-10.2$ \\
\hline Platelets & 193 & 176 & 286 & $142-424$ \\
\hline Hemoglobin & 15.9 & 15.4 & 15.3 & $12.2-18.1$ \\
\hline Bun & 30 & 32 & 13 & $7-18$ \\
\hline Creatinine & 3.1 & 1.1 & 0.9 & $0-1.3$ \\
\hline Sodium & 134 & 141 & 143 & $136-145$ \\
\hline Potassium & 3.5 & 4.7 & 4.1 & $3.5-5.5$ \\
\hline Calcium & 7.5 & 7.3 & 8.9 & $8.5-10.1$ \\
\hline AST & 53 & 128 & 21 & $15-37$ \\
\hline ALT & 43 & 79 & 46 & $30-65$ \\
\hline Albumin & 3 & 2.1 & 3.8 & $3.4-5$ \\
\hline CPK & 2198 & 1307 & 92 & $21-232$ \\
\hline LDH & 251 & 518 & 162 & $100-190$ \\
\hline Myoglobin & $>1000$ & 200 & 30 & $25-70$ \\
\hline Troponin I & $<0.2$ & & & \\
\hline INR & 1.83 & 1.44 & 0.94 & $1-1.5$ \\
\hline Pt & 20.8 & 17.2 & 12.9 & $11-15$ \\
\hline aPTT & 44.00 & 38.5 & 26.9 & $26.5-40$ \\
\hline D-dimer & 2120 & 1500 & 55 & $0-500$ \\
\hline ANA & 0.367 & & & $0-1$ \\
\hline RF & 9.44 & & & $0-15$ \\
\hline TSH & 2.13 & & & $0.4-4$ \\
\hline
\end{tabular}

After this interesting and important finding, the literature was reviewed and recognized that the major problems of our patient including renal insufficiency, hepatic enzyme elevation, rhabdomyolysis, coagulopathy, increased fibrin degrade products were all might be explained by "heat stroke" which is a form of heat-related illness. The patient was followed up in intensive care unit with supportive therapy for a week. After this therapy all of the disturbances and pain of the patient were relieved, all of the abnormal laboratory tests were returned to normal levels, patient was mobilized and skin findings were resolved. He was discharged after three days of follow up in step down unit. Follow up period for three months was eventful.

\section{Discussion}

Heat related disorders vary among minor syndromes including heat cramps, heat syncope, heat exhaustion and serious life threatening conditions such as heat stroke. ${ }^{[1]}$ Heat stroke, emerges as a result of exposure to high temperature, is a disturbance characterized by tachycardia, tachypnea, normal or low blood pressure and elevation of body temperature over $40.6{ }^{\circ} \mathrm{C}$ and can result with complications including renal failure, liver failure, respiratory distress syndrome, rhabdomyolysis and disseminated intravascular coagulation ${ }^{[2,3]}$ Rare heat stroke cases due to electric blankets and rhabdomyolysis due to electric injury were reported. ${ }^{[4,5]}$

In reported case, palpitation, chest pain, shortness of breath, diffuse muscle pain and cold sweating in association with hypoxemia and elevated D-dimer levels lead us suspicion of acute pulmonary embolism. However, normal results of pulmonary computerized tomography angiography and bilateral lower extremity venous color Doppler excluded the diagnosis of acute pulmonary embolism.

After the re-examination of patient history, this clinical situation was considered to be heat stroke despite subfebrile 
fever of the patient. Because, it was stressed that if cooling procedures performed to the patient prior to arrival at the hospital, measured body temperature might be normal or subnormal. ${ }^{[2]}$ Hypoxemia was attributed to inadequate respiration of the patient because of the effects of diffuse rhabdomyolysis to respiratory muscles. Fibrinolysis was considered to cause elevation of D-dimer levels. In a study of 16 cases exposed to heat stroke, from Bouchama et al. It was determined that coagulation and fibrinolysis activated and fibrin degrade products elevated in these patients. ${ }^{[6]}$

Another problem of the patient was limitation of movement because of diffuse muscle pain. As a consequence of absence of inflammatory findings in muscle biopsy obtained from left deltoid muscle, normal rheumatologic tests, reversibility of symptoms, signs and laboratory findings, and healing without sequela excluded inflammatory muscle diseases and related this problem to rhabdomyolysis.

Almost all of the aforementioned complications of heat stroke including renal failure, liver failure, rhabdomyolysis, and elevations of fibrin degrade products and prolongation of prothrombin time and activated partial thromboplastin time were occurred in our patient. All of them were resolved with supportive therapy.

In conclusion, heat stroke is a common condition because of the exposure to high heat wave especially in summer. Clinical manifestations may vary from mild symptoms to life threatening situations, even death. Although, several investigations have been performed about this illness, limi- ted numbers of cases were reported involving heat stroke related to electric blanket. We presented a rare case in literature which survived after heat stroke due to electric blanket. There are no specific management methods; all of the therapies in literature were conservative and symptomatic. Large, detailed investigations are needed to design optimal management methods. However, it is a useful warming tool especially in cold climates; electrical blanket should be used carefully for preventing undesirable events.

\section{Conflict of Interest}

The authors declare that there is no potential conflicts of interest.

\section{References}

1. Lugo-Amador NM, Rothenhaus T, Moyer P. Heat-related illness. Emerg Med Clin North Am 2004;22:315-27, viii. [CrossRef]

2. Tek D, Olshaker JS. Heat illness. Emerg Med Clin North Am 1992;10:299-310.

3. Clowes GH Jr, O'Donnell TF Jr. Heat stroke. N Engl J Med 1974;291:564-7. [CrossRef]

4. Zhou Y, Li L, Liu L, Jia D, Zhang X, Fowler DR, et al. Heat stroke deaths caused by electric blankets: case report and review of the literature. Am J Forensic Med Pathol 2006;27:324-7. [CrossRef]

5. Sungur $M$, Güven $M$. Rhabdomyolysis caused by electric injury. J Emerg Med 2001;20:195-6. [CrossRef]

6. Bouchama A, Bridey F, Hammami MM, Lacombe C, al-Shail E, al-Ohali $Y$, et al. Activation of coagulation and fibrinolysis in heatstroke. Thromb Haemost 1996;76:909-15. 